\title{
Functional Expression of Tumor Necrosis Factor-Related Apoptosis-Inducing Ligand in Human Colonic Adenocarcinoma Cells
}

\author{
Hidekazu Inoue, Katsuya Shiraki, Takenari Yamanaka, Shigeru Ohmori, \\ Takahisa Sakai, Masatoshi Deguchi, Hiroshi Okano, Kazumoto Murata, \\ Kazushi Sugimoto, and Takeshi Nakano
}

First Department of Internal Medicine, Mie University School of Medicine, Tsu, Mie, Japan

\begin{abstract}
SUMMARY: TNF-related apoptosis-inducing ligand (TRAIL) can induce apoptosis in various transformed cell lines. Therefore, we investigated TRAIL sensitivity, TRAIL-induced nuclear factor- $\kappa \mathrm{B}(\mathrm{NF}-\kappa \mathrm{B})$ activation, and expression of TRAIL in human colonic adenocarcinoma cell lines (HT-29, LS180, SK-CO-1). All four TRAIL receptors (TRAIL-R1 through TRAIL-R4) are expressed in these cell lines. TRAIL sensitivity was assessed by assay of cell viability. Cancer cell viabilities were $83 \pm 3.1 \%(\mathrm{HT}-29)$, $90 \pm$ $4.3 \%$ (LS180), and $88 \pm 6.3 \%$ (SK-CO-1) at 24 hours after the addition of $100 \mathrm{ng} / \mathrm{ml} \mathrm{TRAIL}$, indicating that these cell lines were relatively resistant to TRAIL. Activation of NF- $\kappa$ B was variably influenced by TRAIL administration, with no consistent tendency among the cell lines, indicating that TRAIL-induced NF- $\kappa$ B activation might be cell-type dependent. In contrast, TRAIL was expressed in the human colonic adenocarcinoma cell lines by Western blotting and RT-PCR. Increased expression of TRAIL on tumor cells was observed by flow cytometry after cytokine stimulation (IFN- $\gamma, \mathrm{TNF}-\alpha$ ) or the addition of chemotherapeutic agents (camptothecin, doxolubicin hydrochloride). TRAIL on HT-29 cells was functional and able to induce apoptosis in Jurkat cells. Jurkat cell viability was increased by the addition of TRAILR1-R4-Fc. In the presence of various cytokines or chemotherapeutic agents, functional TRAIL is expressed on the surface of tumor cells, and this expressed TRAIL might contribute to tumor immune privilege by inducing apoptosis of activated human lymphocytes. (Lab Invest 2002, 82:1111-1119).
\end{abstract}

7 NF-related apoptosis-inducing ligand (TRAIL) is a TNF family member capable of inducing apoptosis in various transformed cells (Pitti et al, 1996; Wiley et al, 1995). TRAIL is a type II membrane protein of 281 amino acids. Although resistance to TRAILinduced apoptosis is seen in cancer cells (Gliniak and Le, 1999; Lacour et al, 2001; Yamanaka et al, 2000), these cell lines can be sensitized to TRAIL-induced apoptosis by the addition of chemotherapeutic agents (Gliniak and Le, 1999; Lacour et al, 2001; Yamanaka et al, 2000).

TRAIL can induce apoptosis by interaction with two receptors, referred to as TRAIL-R1 (DR4) (Pan et al, 1997a; Schneider et al, 1997a) and TRAIL-R2 (DR5) (MacFarlane et al, 1997; Pan et al, 1997b; Schneider et al, 1997a, 1997b; Sheridan et al, 1997). These receptors have an intracellular death domain that mediates cellular apoptosis. Two other receptors, known as TRAIL-R3 (MacFarlane et al, 1997; Pan et al, 1997b; Schneider et al, 1997b; Sheridan et al, 1997) and TRAIL-R4 (Degli-Esposti et al, 1997; Pan et al, 1998),

DOI: 10.1097/01.LAB.0000027838.69455.39

Received December 6, 2001

This work was supported in part by a research grant for Science from the Ministry of Education, Science, and Culture of Japan.

Address reprint requests to: Dr. Katsuya Shiraki, First Department of Internal Medicine, Mie University School of Medicine, 2-174 Edobashi, Tsu,Mie 514-8507, Japan.E-mail: katsuyas@clin.medic.mie-u.ac.jp inhibit apoptosis by acting as decoy receptors because they do not contain the cytoplasmic death domain. These decoy receptors are highly expressed in normal tissues but have substantially lower expression in malignant cells (Degli-Esposti et al, 1997; Pan et al, 1997b; Sheridan et al, 1997). Soluble TRAIL is unique in that it frequently induces apoptosis of transformed cells in vitro and in xenograft murine models without causing apoptosis of normal cells (Walczak et al, 1999). TRAIL induces apoptosis in various human cancer cells, a promising observation because it raises the possibility of a death ligand with selectivity for tumor cells. Recently, an anti-human DR5 monoclonal antibody induced apoptosis of most TRAILsensitive tumor cells in vitro and in vivo without inducing cell death of normal human hepatocytes (Ichikawa et al, 2001). This result is also hopeful in selective treatment of cancer cells.

TRAIL sensitivity of human colonic adenocarcinoma cell lines has been studied, with variations observed among the cell lines (Gliniak and Le, 1999; Lacour et al, 2001). Colon cancer cell lines also could be sensitized to TRAIL-induced apoptosis by the addition of chemotherapeutic agents (Gliniak and Le, 1999; Lacour et al, 2001).

TRAIL can induce nuclear factor $-\kappa \mathrm{B}(\mathrm{NF}-\kappa \mathrm{B})$ activation in various cancer cells, including hepatocellular carcinoma cell lines (Yamanaka et al, 2000). NF- $\kappa \mathrm{B}$ is a mediator in the inhibition of an apoptotic response, 
and NF- $\kappa \mathrm{B}$ activation has been shown to increase the antiapoptotic threshold of cells and tissues exposed to cytotoxic cytokines by suppressing the initiation of caspase-8 activation (Wang et al, 1998). Thus, TRAILinduced NF- $\kappa$ B activation can inhibit TRAIL-induced apoptosis via the active induction of genes whose products provide resistance to apoptosis.

We have previously shown the involvement of CD40 (TNFR family) (Sugimoto et al, 1999), survivin (antiapoptotic proteins with anticaspase activity) (Ito et al, 2000), and caspase 1 and caspase 3 (cysteine proteases) (Fujikawa et al, 2000) in resistance to apoptosis in tumor cells. Furthermore, previous reports show that Fas ligand (FasL) expression in many human cancer contributes to tumor immune privilege by inducing apoptosis of activated lymphocytes (Peduto Eberl et al, 1999; Mann et al, 1999; O'Connell et al, 1998; Okada et al, 2000; Shiraki et al, 1997; Yoong et al, 1999). However, other data demonstrate that FasL is solely a mediator of inflammation, rather than immune escape (Restifo, 2000). It was hoped that FasL could be exploited to artificially confer immune privilege on organ transplants. However, in numerous experiments, genetically engineered FasL exerted a proinflammatory effect, leading to neutrophilmediated graft rejection (Kang et al, 1997; Restifo, 2000). Although soluble forms of FasL are chemoattractants to neutrophils in vitro, full-length, apoptosisactive FasL seems to be the predominant proinflammatory form in vivo (Hohlbaum et al, 2000). It is unclear whether cancer cells express TRAIL on their cell surface and contribute to this tumor immune privilege.

In this study, we investigated the TRAIL sensitivity of the human colonic adenocarcinoma cell lines HT-29, LS180, and SK-CO-1. We also examined the induction of NF- $\kappa \mathrm{B}$ activation by TRAIL to evaluate the participation in resistance of TRAIL-induced apoptosis and the expression of TRAIL on human colonic adenocarcinoma cell lines to evaluate the participation in pathways that confer tumor immune privilege.

\section{Results}

\section{Expression of TRAIL Receptors in Colonic Adenocarcinoma Cell Lines}

Expression of TRAIL-R1 and TRAIL-R2, with cytoplasmic death domains, was analyzed using Western blotting. The expected bands of TRAIL-R1 and -R2 were observed in all three cell lines (Fig. 1a). Transcripts of TRAIL-R3 and -R4, which have no death domain and function as decoy receptors, were analyzed using RT-PCR methods. As shown in Figure $1 \mathrm{~b}$, a 612-bp RT-PCR fragment of TRAIL-R3 and a 453-bp RT-PCR fragment of TRAIL-R4 were detected in all three cell lines.

\section{TRAIL Sensitivity in Colonic Adenocarcinoma Cell Lines}

We investigated sensitivity to TRAIL in colonic adenocarcinoma cell lines by 3-(4,5-dimethylthiazol-2-yl)2,5-diphenyl tetrazolium bromide (MTT) methods. As a

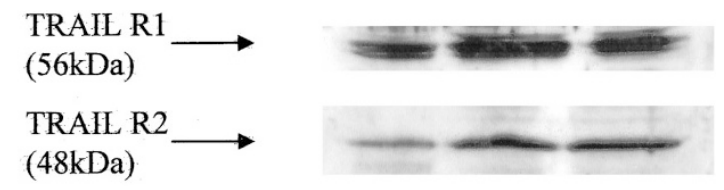

b

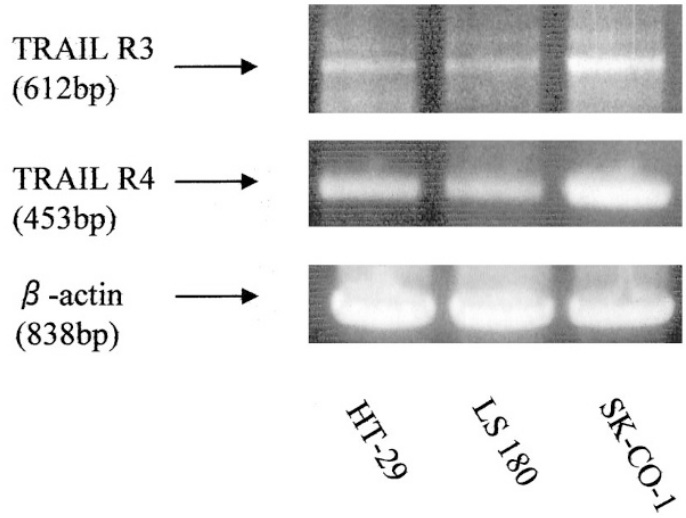

Figure 1.

a, Expression of TNF-related apoptosis-inducing ligand (TRAIL-R1) (56 kDa) and TRAIL-R2 (48 kDa) in human colonic adenocarcinoma cell lines. Cellular lysates were separated by SDS-PAGE and transferred to nitrocellulose. TRAIL-R1 and TRAIL-R2 levels were detected by Western blotting. b, Detection of TRAIL-R3 and TRAIL-R4 mRNA in human colonic adenocarcinoma cell lines by RT-PCR. A 612-bp human TRAIL-R3-specific sequence, a 453-bp TRAILR4-specific sequence, and an 838-bp $\beta$-actin sequence were amplified from total RNA isolated from human colonic adenocarcinoma cell lines, separated by agarose gel electrophoresis, and visualized by ethidium bromide staining.

shown in Figure 2, cell viability decreased somewhat (a, HT-29, $83 \pm 3.1 \%$; b, LS180, $90 \pm 4.3 \%$; c, SK-CO-1, $88 \pm 6.3 \%$ ) with $100 \mathrm{ng} / \mathrm{ml} \mathrm{TRAIL}$, and the degree of the decrease differed between the three
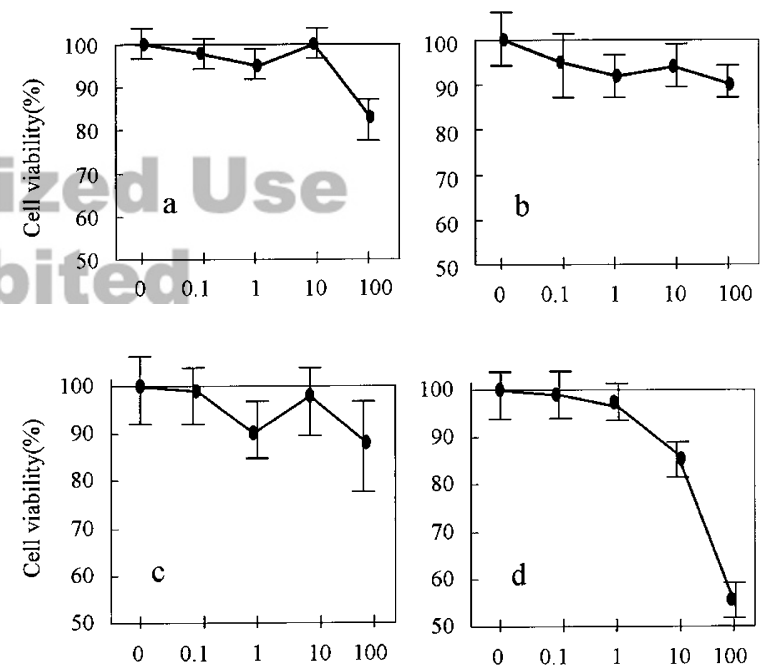

TRAIL (ng/ml)

\section{Figure 2.}

Effect of TRAIL stimulation in human colonic adenocarcinoma cell lines (a) HT-29, (b) LS180, (c) SK-C0-1, and (d) Jurkat cells. Cells were incubated with various concentrations of TRAIL for 24 hours. Cell viability was assessed by 3-(4,5-dimethylthiazol-2-yl)-2,5-diphenyl tetrazolium bromide (MTT) assay. The data shown are the mean \pm SD of eight independent experiments. 
colonic adenocarcinoma cell lines. A concentration of $100 \mathrm{ng} / \mathrm{ml}$ of TRAIL did induce $45 \%$ apoptosis in Jurkat cells (Fig. 2d), which are sensitive to TRAILinduced apoptosis.

\section{TRAIL-Induced NF-кB Activation in Colonic Adenocarcinoma Cell Lines}

Because of the minimal TRAIL sensitivity in the colonic adenocarcinoma cell lines observed above, we investigated another TRAIL pathway that relies on NF- $\kappa$ B activation to increase the antiapoptotic threshold of cells. TRAIL-induced NF- $\kappa \mathrm{B}$ activation was observed only in HT-29 cells (Fig. 3a) in a dose-dependent

a

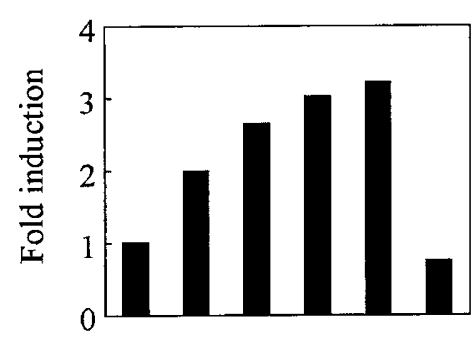

$\begin{array}{lllllll}0 & 0.1 & 1 & 10 & 100 & 100+\mathrm{I} \kappa \mathrm{B}\end{array}$

TRAII

(ng/ml)

b

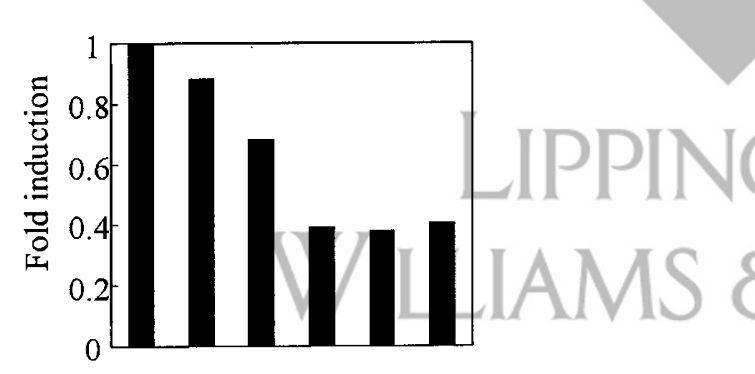

$\begin{array}{llllllllll}0 & 0.1 & 1 & 10 & 100 & 100+\text { IkB } & \text { TRAIL }\end{array}$

$(\mathrm{ng} / \mathrm{ml})$ manner. In contrast, NF- $\kappa$ B activation in LS180 cells was gradually decreased by TRAIL administration (Fig. 3b). In SK-CO-1 cells (Fig. 3c), NF- $\kappa$ B activation was not obviously affected by TRAIL administration. NF- $\kappa B$ activation was decreased by cotransfection of pCMV$I_{\kappa} \mathrm{B} \alpha$ in three colonic adenocarcinoma cell lines (Fig. 3). NF- $\kappa B$ activation was significantly increased by TNF- $\alpha$ administration in three colonic adenocarcinoma cell lines (data not shown).

\section{Expression of TRAIL in Colonic Adenocarcinoma Cell Lines}

Expression of TRAIL was analyzed using Western blotting. The expected bands corresponding to TRAIL were observed in all three colonic adenocarcinoma cell lines: HT-29, LS180, and SK-CO-1 (Fig. 4a). To investigate the expression of TRAIL MRNA in colonic adenocarcinoma cell lines, total RNA was extracted from subconfluent cell cultures and analyzed by RTPCR. Human $\beta$-actin CDNA was used as an internal control. As shown in Figure 4b, a 414-bp RT-PCR fragment of TRAIL was detected in all three colonic adenocarcinoma cell lines.

\section{Cell-Surface Expression of TRAIL induced by IFN- $\gamma$,} TNF- $\alpha$, Camptothecin, and Doxolubicin Hydrochloride

The expression of TRAIL on the cell surface of colonic adenocarcinoma cell lines after 24 hours of stimulation with IFN- $\gamma$, TNF- $\alpha$, camptothecin, or doxolubicin hydrochloride was investigated using flow cytometric analysis. In HT-29 cells, IFN- $\gamma$ enhanced TRAIL expression slightly (Fig. 5a), whereas TNF- $\alpha$ had no effect (Fig/ 5b). Camptothecin also enhanced TRAIL expression slightly (Fig. 5c), whereas doxolubicin hydrochloride increased TRAIL expression significantly (Fig. 5 d). In LS180 cells, IFN- $\gamma$, TNF- $\alpha$, or camptothecin enhanced TRAIL expression slightly (Fig. 6, a to c)

TRAIL $(36 \mathrm{kDa})$

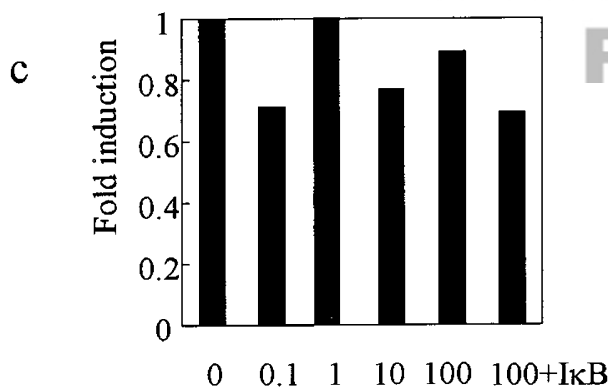

TRAIL (ng/ml)

Figure 3.

TRAIL-induced nuclear factor- $\kappa \mathrm{B}$ (NF- $\kappa \mathrm{B}$ ) activation in human colonic adenocarcinoma cell lines (a) HT-29, (b) LS180, and (c) SK-C0-1. Cells were transfected with pNF- $\kappa \mathrm{B}-\mathrm{Luc}$ vector. Transfection with $\mathrm{pCMV}-\mathrm{I}_{\kappa} \mathrm{B} \alpha$ vector was performed as a negative control. NF- $\kappa \mathrm{B}$ activation was analyzed using an $\mathrm{NF}-\kappa \mathrm{B}-$-luciferase reporter gene assay. The results are presented as fold induction of the luciferase activity observed in cells incubated with the indicated concentration of TRAIL for 24 hours compared with that of cells without TRAIL.

\section{Figure 4.}

a, Expression of TRAIL (36 kDa) in human colonic adenocarcinoma cell lines. Cellular lysates were separated by SDS-PAGE and transferred to nitrocellulose. TRAIL levels were detected by Western blotting. $b$, Detection of TRAIL mRNA in human colonic adenocarcinoma cell lines by RT-PCR. A 414-bp human TRAIL-specific sequence and an 838-bp $\beta$-actin sequence were amplified from total RNA isolated from human colonic adenocarcinoma cell lines, separated by agarose gel electrophoresis, and visualized by ethidium bromide staining. 

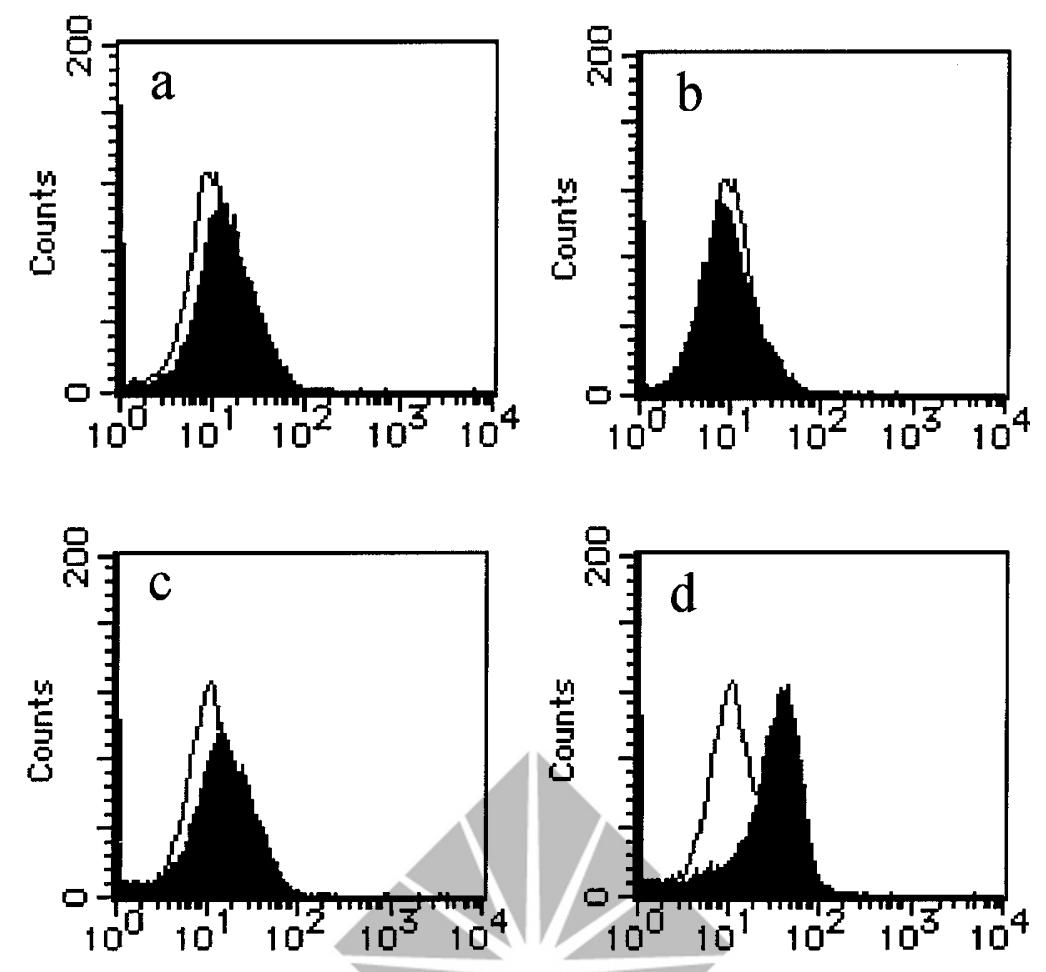

Figure 5.

Expression of TRAIL in HT-29 cells analyzed by flow cytometry. Open histogram indicates cells stained with FITC-conjugated mouse-lgG (as control); filled histogram indicates cells stained with FITC-conjugated TRAIL-R2Fc after incubation with (a) $400 \mathrm{U} / \mathrm{ml} \mathrm{IFN-} \gamma$, (b) $100 \mathrm{ng} / \mathrm{ml} \mathrm{TNF}-\alpha$, (c) $10 \mu \mathrm{g} / \mathrm{ml}$ camptothecin, or (d) $1 \mu \mathrm{g} / \mathrm{ml}$ doxolubicin hydrochloride for 24 hours.

and doxolubicin hydrochloride again enhanced TRAIL expression significantly (Fig. $6 \mathrm{~d}$ ). Similar results were observed in the SK-CO-1 cells (Fig. 7, a to d).

\section{Apoptosis in Jurkat Cells Induced by TRAIL Expressed in HT-29 Cells}

To address the question of whether the cell-surface TRAIL was functional, increased TRAIL expression in HT-29 cells was induced by doxolubicin hydrochloride. The cells were fixed, and Jurkat cells were added with or without anti-human FasL antibody and human recombinant TRAILR1-R4-Fc, which binds to TRAIL and inhibits TRAIL activity. Cell viability of Jurkat cells decreased to $48 \pm 11 \%$ compared with Jurkat cell viability without stimulation of HT-29 cells with doxolubicin hydrochloride (Fig. 8). Cell viability of Jurkat cells was $57 \pm 25 \%$ in the presence of only antihuman FasL antibody and $86 \pm 11 \%$ in the presence of only human recombinant TRAILR1-R4-Fc. Cell viability of the Jurkat cells was $100 \pm 20 \%$ with both anti-human FasL antibody and human recombinant TRAILR1-R4-Fc. Apoptosis of Jurkat cells cocultured with doxolubicin-treated HT-29 cells was observed with 4'6,-diamidino-2-phenylindole (DAPI) staining (Fig. 9a), but the addition of human recombinant TRAILR1-R4-Fc protected the Jurkat cells from apoptosis (Fig. 9b).

\section{Discussion}

TRAIL is a member of the TNF family that is a type II membrane protein of 281 amino acids and is capable of inducing apoptosis in various transformed cells (Pitti et al, 1996; Wiley et al, 1995). TRAIL can induce apoptosis by interaction with two receptors, referred to as TRAlL-R1 (DR4) (Pan et al, 1997a; Schneider et al, 1997a) and TRAIL-R2 (DR5) (MacFarlane et al, 1997; Pan et al,1997b; Schneider et al, 1997a, 1997b; Sheridan et al, 1997). These receptors have a death domain that mediates cellular apoptosis. Two other receptors, known as TRAIL-R3 (MacFarlane et al, 1997; Pan et al, 1997b; Schneider et al, 1997b; Sheridan et al, 1997) and TRAIL-R4 (Degli-Esposti et al, 1997; Pan et al, 1998), inhibit apoptosis by acting as decoy receptors because they do not contain the cytoplasmic death domain. These decoy receptors are highly expressed in normal tissues but have substantially lower expression in malignant cells (DegliEsposti et al, 1997; Pan et al, 1997b; Sheridan et al, 1997). In the current study, we observed that TRAIL modulated NF- $\kappa \mathrm{B}$ signaling, suggesting the existence of TRAIL receptors on the cell surface. In fact, we detected TRAIL receptors using Western blotting or RT-PCR.

We assayed TRAIL-induced apoptosis in the human colonic adenocarcinoma cell lines using the MTT method and found that the cells were relatively resistant to exogenous TRAIL. Decoy receptors might contribute to resistance against TRAIL-induced apoptosis in these carcinoma cells. Previous reports showed that colon cancer cell lines could be sensitized to TRAIL-induced apoptosis by the addition of chemotherapeutic agents (Gliniak and Le, 1999; La- 

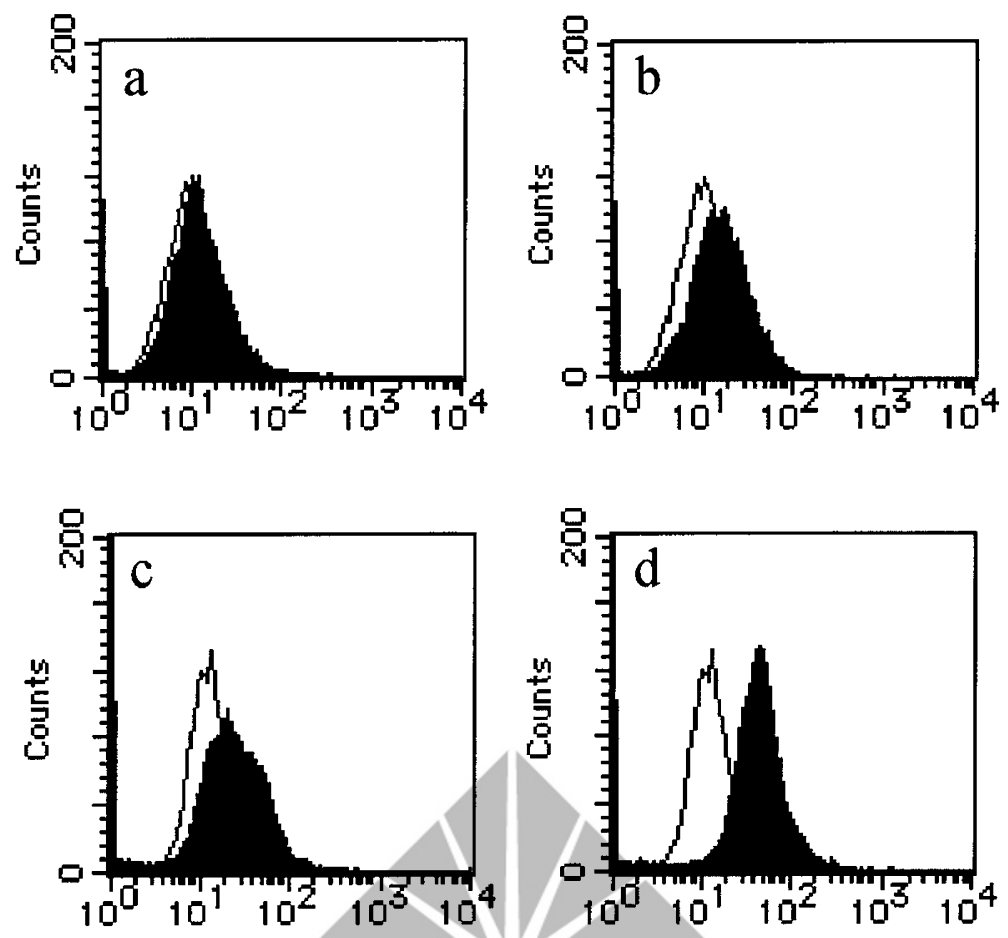

Figure 6.

Expression of TRAIL in LS180 cells analyzed by flow cytometry. Open histogram indicates cells stained with FITC-conjugated mouse-lgG (as control); filled histogram indicates cells stained with FITC-conjugated TRAIL-R2Fc after incubation with (a) $400 \mathrm{U} / \mathrm{ml} \mathrm{IFN-} \gamma$, (b) $100 \mathrm{ng} / \mathrm{ml} \mathrm{TNF-} \alpha$, (c) $10 \mu \mathrm{g} / \mathrm{ml}$ camptothecin, or (d) $1 \mu \mathrm{g} / \mathrm{ml}$ doxolubicin hydrochloride for 24 hours.
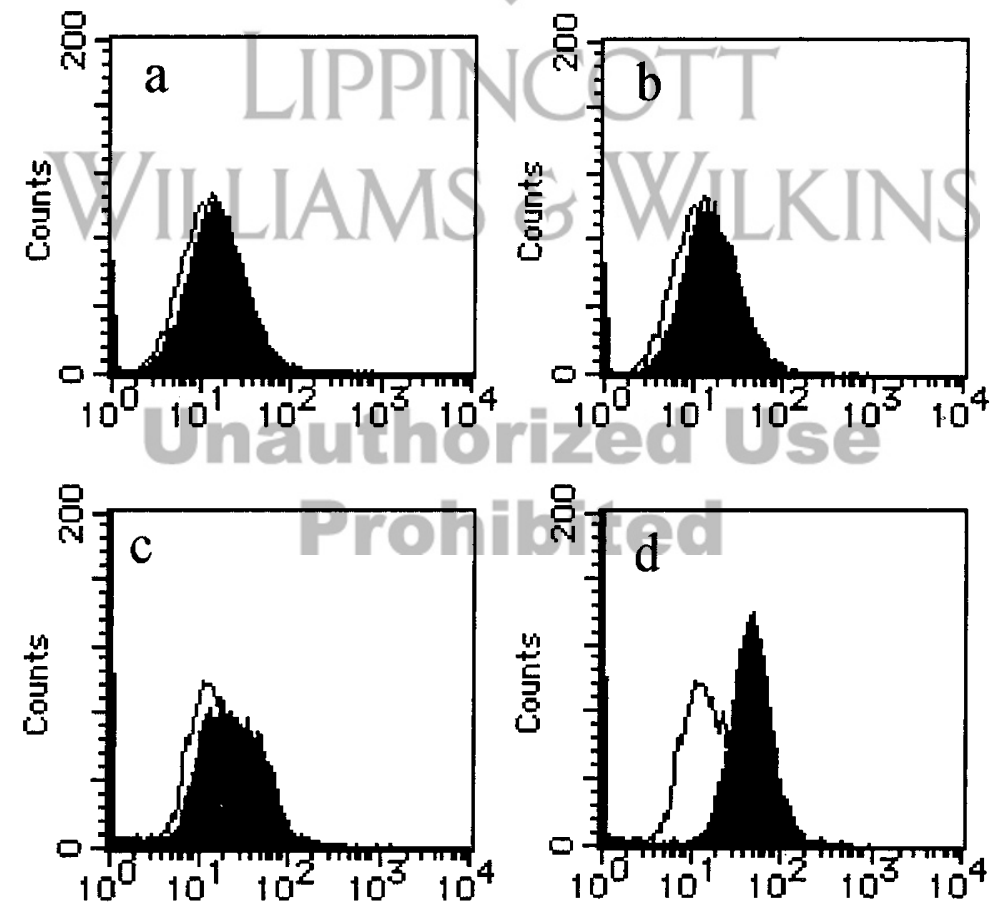

Figure 7.

Expression of TRAIL in SK-C0-1 cells analyzed by flow cytometry. Open histogram indicates cells stained with FITC-conjugated mouse-IgG (as control); filled histogram indicates cells stained with FITC-conjugated TRAIL-R2Fc after incubation with (a) $400 \mathrm{U} / \mathrm{ml} \mathrm{IFN-} \gamma$, (b) $100 \mathrm{ng} / \mathrm{ml} \mathrm{TNF-} \alpha$, (c) $10 \mu \mathrm{g} / \mathrm{ml}$ camptothecin, or (d) $1 \mu \mathrm{g} / \mathrm{ml}$ doxolubicin hydrochloride for 24 hours.

cour et al, 2001). Cytotoxic drugs lower the signaling threshold required for TRAIL-induced procaspase-8 activation (Lacour et al, 2001). Therefore, we consid- ered whether TRAIL and chemotherapeutic agents were needed to induce cell apoptosis in human coIonic adenocarcinoma cell lines. 


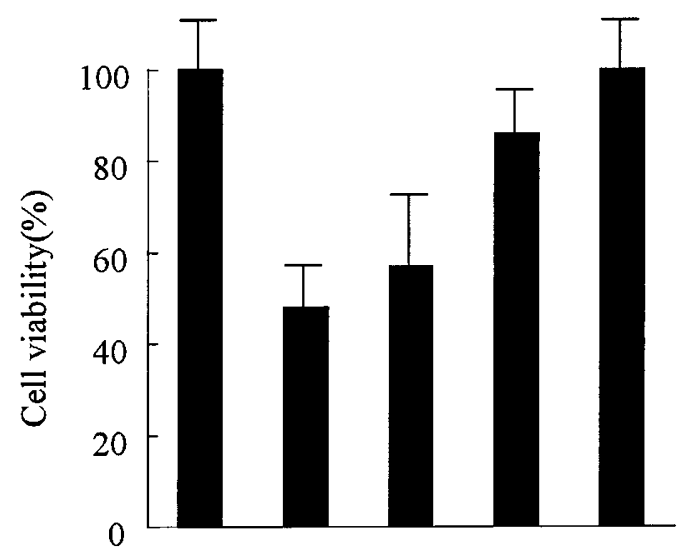

$\begin{array}{lccccc}\text { doxolubicin } & - & + & + & + & + \\ \text { Anti-FasL-Ab } & - & - & + & - & + \\ \text { TRAIL } & - & - & - & + & + \\ \text { R1-R4-Fc } & & & & & \end{array}$

Figure 8.

MTT assay of Jurkat cells cocultured with fixed HT-29 cells with or without prior stimulation with $1 \mu \mathrm{g} / \mathrm{ml}$ doxolubicin hydrochloride for 24 hours in the presence of Fas ligand antibody or TRAILR1-R4-Fc or both. The data shown are the mean $\pm S D$ of four independent experiments.

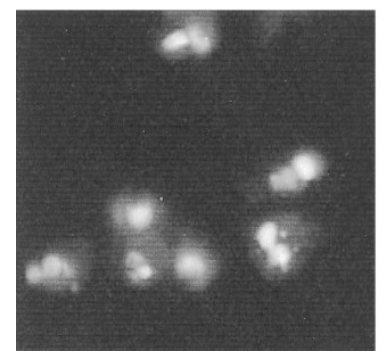

b

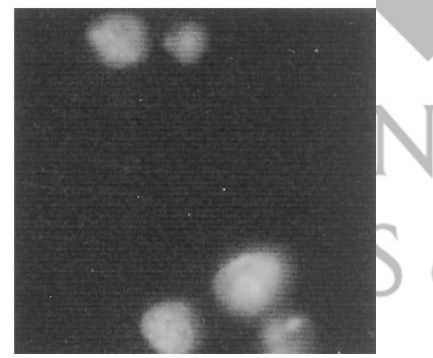

Figure 9.

DAPI (4'6,-diamidino-2-phenylindole) staining of Jurkat cells cocultured with HT-29 cells after stimulation with $1 \mu \mathrm{g} / \mathrm{ml}$ doxolubicin hydrochloride for 24 hours in the absence (a) or presence (b) of TRAILR1-R4-Fc.

In a previous study, TRAIL induced NF- $\kappa \mathrm{B}$ in hepatocellular carcinoma cell lines (Yamanaka et al, 2000). $\mathrm{NF}-\kappa \mathrm{B}$ is a mediator in the inhibition of an apoptotic response, and $\mathrm{NF}-\kappa \mathrm{B}$ activation has been shown to increase the antiapoptotic threshold of cells and tissues exposed to cytotoxic cytokines by suppressing the initiation of caspase-8 activation (Wang et al, 1998). TRAIL induction of NF- $\kappa$ B activation can inhibit TRAIL-induced apoptosis via the active induction of genes whose products provide resistance to apoptosis. We assayed TRAIL-induced NF- $\kappa$ B activation using the pNF- $\kappa \mathrm{B}-$ Luc vector and after luciferase activity. The NF- $\kappa$ B activation by exogenous TRAIL treatment varied among the three cell lines, from increased activation (HT-29) to decreased activation (LS180) to no response (SK-CO-1). The role of NF- $\kappa \mathrm{B}$ pathways, therefore, seems to be fairly complex and may be affected by cell type or the specific defects contributing to transformation.
Previous reports show that FasL expression in many human cancers contribute to tumor immune privilege by inducing apoptosis of activated lymphocytes (Mann et al, 1999; O'Connell et al, 1998; Okada et al, 2000; Peduto Eberl et al, 1999; Shiraki et al, 1997; Yoong et al, 1999). In colon cancer, FasL expression was associated with increased apoptosis of tumorinfiltrating lymphocytes, and reduced tumor-infiltrating lymphocytes have in turn been associated with poorer prognosis (Mann et al, 1999). FasL might favor metastasis to other sites where local cell populations are sensitive to Fas-mediated apoptosis. FasL is upregulated in liver metastases relative to matched primary tumors in colon cancer (O'Connell et al, 1998). FasL also promotes successful allograft survival of FasL-expressing tissues (Bellgrau et al, 1995; Stuart et al, 1997) or of nonimmune-privileged cells (pancreatic islets) cotransplanted with FasL-expressing cells (Korbutt et al, 1997; Lau et al, 1996). However, in numerous experiments, genetically engineered FasL exerted a proinflammatory effect, leading to neutrophilmediated graft rejection (Restifo, 2000; Kang et al, 1997). Although soluble forms of FasL can attract neutrophils in vitro, full-length, apoptosis-active FasL seems to be the predominant proinflammatory form in vivo (Hohlbaum et al, 2000).

We found that TRAIL was expressed in the human colonic adenocarcinoma cell lines using Western blotting and RT-PCR. Surprisingly, increased expression of TRAIL on tumor cells was observed by flow cytometry after cytokine stimulation (IFN- $\gamma, \operatorname{TNF}-\alpha)$ or the addition of chemotherapeutic agents (camptothecin, doxolubicin hydrochloride). Similar result was reported on keratinocytes after IFN- $\gamma$ stimulation (Qin et al, 2001). This expression of TRAIL was functional because it was based on the ability of TRAIL to induce Jurkat cell apoptosis by coculture with stimulated HT-29 cells. Furthermore, Jurkat cell viability was increased by the addition of TRAILR1-R4-Fc. Cell viability after the addition of only TRAILR1-R4-Fc $(86 \%)$ was higher than with only anti-FasL-antibody (57\%) in our Jurkat HT-29 coculture study. These results support the notion that functional TRAIL on the surface of tumor cells may contribute more than FasL to induce apoptosis of Jurkat cells in the presence of cytokines or chemotherapeutic agents. Thus, TRAIL expressed on tumor cells might contribute to tumor immune privilege by inducing apoptosis of activated human lymphocytes.

In summary, human colonic adenocarcinoma cell lines were relatively resistant to exogenous TRAIL. $\mathrm{NF}-\kappa \mathrm{B}$ activation was variably influenced by TRAIL administration, with no consistent observations among the three cell lines, indicating TRAIL-induced $\mathrm{NF}-\kappa \mathrm{B}$ activation might be cell-type dependent. We have shown that TRAIL was expressed in human colonic adenocarcinoma cell lines and increased expression of functional TRAIL was observed after treatment with some cytokines or chemotherapeutic agents. These results indicate that TRAIL expressed on the surface of tumor cells might contribute to tumor immune privilege. Further studies are needed to ad- 
dress the molecular basis and signaling pathways important in TRAIL expression in human adenocarcinoma cells.

\section{Materials and Methods}

\section{Cell Lines}

The human colonic adenocarcinoma cell lines HT-29, LS180, and SK-CO-1, and the Jurkat human T leukemia cell line were purchased from American Type Culture Collection (Rockville, Maryland). All cell lines were maintained in DMEM (Sigma, St. Louis, Missouri) supplemented with $10 \%$ heat-inactivated fetal bovine serum (GIBCO BRL, Rockville, Maryland) and 1\% penicillin/streptomycin (GIBCO BRL).

\section{Detection of TRAIL and TRAIL Receptor Transcript}

The expression of TRAIL, TRAIL-R3, and TRAIL-R4 mRNA was determined by RT of total RNA followed by PCR analysis (RT-PCR). Approximately $10^{7}$ human colonic adenocarcinoma cells was homogenized with $1 \mathrm{ml}$ of Ultraspec RNA reagent (Biotecx Laboratories, Houston, Texas) using a Mini-Beadbeater (Biospec Products, Bartlesville, Oklahoma), and total RNA was isolated according to the manufacturer's protocol. cDNA was synthesized by extension of (dT) $)_{12-18}$ primers with $200 \mathrm{U}$ of SuperScript II reverse transcriptase (GIBCO BRL) in a mixture containing $2 \mu \mathrm{g}$ of total RNA for 50 minutes at $42^{\circ} \mathrm{C}$. PCR of the CDNA was performed in a final volume of $50 \mu \mathrm{l}$ containing all four dNTPs (each at $200 \mu \mathrm{mol} / \mathrm{L}$ ), $2.5 \mathrm{mmol} / \mathrm{L} \mathrm{MgCl} 2,2.5 \mathrm{U}$ of EX Taq (Takara Shuzo, Kyoto, Japan), and each primer at $0.4 \mathrm{~mol} / \mathrm{L}$. The amplification cycles were $94^{\circ} \mathrm{C}$ for 1 minute, $60^{\circ} \mathrm{C}$ for 1 minute, and $72^{\circ} \mathrm{C}$ for 2 minutes for 35 cycles. The PCR-amplified products were run on a $1 \%$ agarose gel containing ethidium bromide and were visualized under ultraviolet light. Amplification of human $\beta$-actin served as a control for sample loading and integrity. The sequences for the relevant primers were as follows: the TRAlL sense primer was 5'-AGACCTGCGTGCTGATCGTG-3' and the TRAIL antisense primer was 5'-TTATITTGCGGCCCAGAGCC-3'; the TRAIL-R3 sense primer was 5'-GAAGAATTTGGTGCCAATGCCACT- $3^{\prime}$ and the TRAIL-R3 antisense primer was 5'-CTCTTGGACTTGGCTGGGAGATGT-3'; the TRAIL-R4 sense primer was 5'-CTITTCCGGCGGCGTTCATGTCCT-3' and the TRAIL-R4 antisense primer was 5'-GTTTCTTCCAGGCTGCTTCCCTTTGTA-3'. The $\beta$-actin sense primer was 5'-ATCTGGCACCACACCTTCTACAATGAGCTGCG-3' and the $\beta$-actin antisense primer was 5'-CGTCATACTCCTGCTTGCTGATCCACATCTGC-3' .

\section{Immunoblotting of TRAIL and TRAIL Receptors}

Expression of TRAIL, TRAIL-R1, and TRAIL-R2 was analyzed by Western blotting. Cell extracts of colonic adenocarcinoma cell lines were homogenized in lysis buffer $(50 \mathrm{mmol} / \mathrm{L}$ Tris- $\mathrm{HCl}$ (pH 8.0), $150 \mathrm{mmol} / \mathrm{L} \mathrm{NaCl}$, $5 \mathrm{mmol} / \mathrm{L}$ ethylenediaminetetraacetic acid, $1 \% \mathrm{NP} 40$, and $1 \mathrm{mmol} / \mathrm{L}$ phenylmethyl sulfonyl fluoride), and equal amounts of protein from each extract were separated by $14 \%$ SDS-PAGE and transferred to cellulose nitrate membranes (Toyo Roshi, Tokyo, Japan). Blots were blocked by incubating in $5 \%$ milk with Tris- $\mathrm{HCl}(\mathrm{pH} 7.5)$ and $0.1 \%$ Tween 20 overnight at $4^{\circ} \mathrm{C}$ and probed overnight at $4^{\circ} \mathrm{C}$ with rabbit antiTRAIL polyclonal antibody (Santa Cruz Biotechnology, Santa Cruz, California), with rabbit anti-DR4 (TRAILR1) polyclonal antibody (Santa Cruz Biotechnology) or with goat anti-DR5 (TRAIL-R2) polyclonal antibody (Santa Cruz Biotechnology). Antibodies were diluted 1:1000 with $5 \%$ milk in Tris- $\mathrm{HCl}(\mathrm{pH} 7.5)$ and $0.1 \%$ Tween 20. The immunoblots were probed with horseradish peroxidase-conjugated anti-rabbit IgG or horseradish peroxidase-conjugated anti-goat IgG (1:2000 diluted with $5 \%$ milk in Tris- $\mathrm{HCl} ; \mathrm{pH} 7.5$ ). After the final wash, signal was detected with an ECL kit (Amersham Pharmacia Biotech, Buckinghamshire, United Kingdom).

\section{Detection of Apoptosis}

To assess the viability of colonic adenocarcinoma cells, the MTT assay was performed. The cells were plated at a density of $5 \times 10^{3}$ cells/well in 96-well microtiter plates (Corning Glass Works, Corning, New York), and each plate was incubated for 24 hours at $37^{\circ} \mathrm{C}$ in $5 \% \mathrm{CO}_{2}$. Recombinant human TRAIL $(0.1,1$, 10 , and $100 \mathrm{ng} / \mathrm{ml}$; R\&D Systems, Minneapolis, Minnesota) was added, and the plates were incubated for 24 hours. The live-cell count was assayed using a Cell Titer 96 Assay kit (Promega, Madison, Wisconsin) according to the manufacturer's instructions. The absorbance of each sample was measured at $570 \mathrm{~nm}$ with a microtiter plate reader (Bio-Rad Laboratories, Hercules, California).

\section{NF-кB Luciferase Reporter Gene Assay}

The pNF- $\kappa \mathrm{B}$-Luc vector (Mercury Pathway Profiling System) and the $\mathrm{pCMV}-\mathrm{I}_{\kappa} \mathrm{B} \alpha$ vector were obtained from Clontech (San Diego, California). Cells $\left(2 \times 10^{5}\right)$ were grown in 6-well plates (Narge Nunc International, Naperville, Illinois) the day before transfection. Cells were transfected using FuGENE6 (Roche, Indianapolis, Illinois) and incubated for 24 hours at $37^{\circ} \mathrm{C}$. The medium was changed to include recombinant human TRAIL $(0.1,1,10$, and $100 \mathrm{ng} / \mathrm{ml})$ and incubated for 24 hours at $37^{\circ} \mathrm{C}$. Luciferase activity was determined from cell extracts by means of a luciferase assay system (Promega) and a luminometer (Berthold Analytical Instruments, Nashua, New Hampshire). The results are presented as the fold induction above the luciferase activity found in cells without stimulation.

\section{Detection of TRAIL by Flow Cytometry}

Cells were grown in 60-mm dishes for 24 hours. The medium was then changed to one with or without 400 $\mathrm{U} / \mathrm{ml}$ IFN- $\gamma$ (Daiichi Pharmaceutical, Tokyo, Japan), $100 \mathrm{ng} / \mathrm{ml}$ TNF- $\alpha$ (Genzyme-Techne, Cambridge, Massachusetts), $10 \mu \mathrm{g} / \mathrm{ml}$ camptothecin (Sigma), or 1 $\mu \mathrm{g} / \mathrm{ml}$ doxolubicin hydrochloride (Sigma) and incu- 
bated for another 24 hours. Cells were washed twice with PBS, harvested with $0.02 \%$ EDTA in PBS, and incubated for 2 hours on ice with FITC-conjugated TRAIL-R2Fc (Alexis, San Diego, California) or control FITC-conjugated mouse IgG (Santa Cruz Biotechnology) at a concentration of $5 \mu \mathrm{g} / \mathrm{ml}$. After two washes with PBS, the cells were analyzed for TRAIL expression by FACScan using CellQuest software (Becton Dickinson, Tokyo, Japan).

\section{Cytotoxic Assay}

HT-29 cells $\left(10^{5}\right)$ were cultured in 24-well plates (Narge Nunc International) for 24 hours at $37^{\circ} \mathrm{C}$, followed by incubation in the absence or presence of $1 \mu \mathrm{g} / \mathrm{ml}$ doxolubicin hydrochloride at $37^{\circ} \mathrm{C}$ for another 24 hours. Cells were fixed in $2 \%$ paraformaldehyde, and Jurkat cells $\left(10^{5}\right)$ were added with or without anti-human FasL antibody (Medical \& Biological Laboratories, Nagoya, Japan) and human recombinant TRAILR1-R4-FC (Alexis). Twenty four hours after Jurkat cells were added, they were placed in 96-well microtiter plates, and the MTT assay was performed to assess the cell viability. Jurkat cell nuclei were stained with DAPI (Sigma) and observed with a fluorescence microscope (Zeiss, Gottingen, Germany).

\section{References}

Bellgrau D, Gold D, Selawry H, Moore J, Franzusoff A, and Duke RC (1995). A role for CD95 ligand in preventing graft rejection. Nature 377:630-632.

Degli-Esposti MA, Dougall WC, Smolak PJ, Waugh JY, Smith CA, and Goodwin RG (1997). The novel receptor TRAIL-R4 induces NF- $\kappa$ B and protects against TRAIL-mediated apoptosis, yet retains an incomplete death domain. Immunity $7: 813-820$

Fujikawa K, Shiraki K, Sugimoto K, Ito T, Yamanaka T, Takase K, and Nakano T (2000). Reduced expression of ICE/caspase1 and CPP32/caspase3 in human hepatocellular carcinoma. Anticancer Res 20:1927-1932.

Gliniak B and Le T (1999). Tumor necrosis factor-related apoptosis-inducing ligand's antitumor activity in vivo is enhanced by the chemotherapeutic agent CPT-11. Cancer Res 59:6153-6158.

Hohlbaum AM, Moe S, and Marshak-Rothstein A (2000). Opposing effects of transmembrane and soluble Fas ligand expression on inflammation and tumor cell survival. J Exp Med 191:1209-1219.

Ichikawa K, Liu W, Zhao L, Wang Z, Liu D, Ohtsuka T, Zhang H, Mountz JD, Koopman WJ, Kimberly RP, and Zhou T (2001). Tumoricidal activity of a novel anti-human DR5 monoclonal antibody without hepatocyte cytotoxicity. Nat Med 7:954-960.

Ito T, Shiraki K, Sugimoto K, Yamanaka T, Fujikawa K, Ito M, Takase K, Moriyama M, Kawano H, Hayashida M, Nakano T, and Suzuki A (2000). Survivin promotes cell proliferation in human hepatocellular carcinoma. Hepatology 31:10801085.

Kang SM, Schneider DB, Lin Z, Hanahan D, Dichek DA, Stock PG, and Baekkeskov S (1997). Fas ligand expression in islets cell of Langerhans does not confer immune privilege and instead targets them for rapid destruction. Nature Med 3:738-743.

Korbutt GS, Elliott JF, and Rajotte RV (1997). Cotransplantation of allogeneic islets with allogeneic testicular cell aggregates allows long-term graft survival without systemic immunosuppression. Diabetes 46:317-322.

Lacour S, Hammann A, Wotawa A, Corcos L, Solary E, and Dimanche-Boitrel MT (2001). Antitumor agents sensitize tumor cells to tumor necrosis factor-related apoptosisinducing ligand-mediated caspase-8 activation and apoptosis. Cancer Res 61:1645-1651.

Lau HT, Yu M, Fontana A, and Stoeckert CJ Jr (1996). Prevention of islet allograft rejection with engineered myoblasts expressing FasL in mice. Science 270:109-112.

MacFarlane M, Ahmad M, Srinivasula SM, FernandesAlnemri T, Cohen GM, and Alnemri ES (1997). Identification and molecular cloning of two novel receptors for the cytotoxic ligand TRAIL. J Biol Chem 272:25417-25420.

Mann B, Gratchev A, Bohm C, Hanski ML, Foss HD, Demel G, Trojanek B, Schmidt-Wolf I, Stein H, Riecken EO, Buhr HJ, and Hanski $C$ (1999). FasL is more frequently expressed in liver metastases of colorectal cancer than in matched primary carcinomas. Br J Cancer 79:1262-1269.

O'Connell J, Bennett MW, O'Sullivan GC, Roche D, Kelly J, Collins JK, and Shanahan F (1998). Fas ligand expression in primary colon adenocarcinomas: Evidence that the Fas counterattack is a prevalent mechanism of immune evasion in human colon cancer. J Pathol 186:240-246.

Okada K, Komuta K, Hashimoto S, Matsuzaki S, Kanematsu $T$, and Koji-T (2000). Frequency of apoptosis of tumorinfiltrating lymphocytes induced by Fas counterattack in human colorectal carcinoma and its correlation with prognosis. Clin Cancer Res 6:3560-3564.

Pan G, O'Rourke K, Chinnaiyan AM, Gentz R, Ebner R, Ni J, and Dixit VN (1997a). The receptor for the cytotoxic ligand TRAIL. Science 276:111-113.

Pan G, Ni J, Wei YF, Yu GL, Gentz R, and Dixit VM (1997b). An antagonist decoy receptor and a death domaincontaining receptor for TRAIL. Science 277:815-818.

Pan G, Ni J, Yu GL, Wei YF, and Dixit VM (1998). TRUNDD, a new member of the TRAIL receptor family that antagonizes TRAIL signaling. FEBS Lett 424:41-45.

Peduto Eberl LP, Guillou L, Saraga E, Schroter M, French LE, Tschopp J, and Juillerat-Jeanneret L (1999). Fas and Fas ligand expression in tumor cells and in vascular smoothmuscle cells of colonic and renal carcinomas. Int $\mathrm{J}$ Cancer 81:772-778.

Pitti RM, Marsters SA, Ruppert S, Donahue CJ, Moore A, and Ashkenazi A (1996). Induction of apoptosis by Apo-2 ligand, a new member of the tumor necrosis factor cytokine family. J Biol Chem 271:12687-12690.

Qin JZ, Bacon P, Chaturvedi V, and Nickoloff BJ (2001). Role of NF- $\kappa \mathrm{B}$ activity in apoptotic response of keratinocytes mediated by interferon- $\gamma$, tumor necrosis factor- $\alpha$, and tumor-necrosis-factor-related apoptosis-inducing ligand. J Invest Dermatol 117:898-907.

Restifo NP (2000). Not so Fas: Re-evaluating the mechanisms of immune privilege and tumor escape. Nature Med 6:493-495. 
Schneider P, Bodmer JL, Thome M, Hofmann K, Holler N, and Tschopp J (1997b). Characterization of two receptors for TRAIL. FEBS Lett 416:329-334.

Schneider P, Thome M, Burns K, Bodmer JL, Hofmann K, Kataoka T, Holler N, and Tschopp J (1997a). TRAIL receptor 1 (DR4) and 2 (DR5) signal FADD-dependent apoptosis and activate NF- $\kappa$ B. Immunity 7:831-836.

Sheridan JP, Marsters SA, Pitti RM, Gurney A, Skubatch M, Baldwin D, Ramakrishnan L, Gray CL, Baker K, Wood WI, Goddard AD, Godowski P, and Ashkenazi A (1997). Control of TRAIL-induced apoptosis by a family of signaling and decoy receptors. Science 277:818-821.

Shiraki K, Tsuji N, Shioda T, Isselbacher KJ, and Takahashi H (1997). Expression of Fas ligand in liver metastases of human colonic adenocarcinomas. Proc Natl Acad Sci USA 94:64206425.

Stuart PM, Griffith TS, Usui N, Pepose J, Yu X, and Ferguson TA (1997). CD95 ligand (FasL)-induced apoptosis is necessary for corneal allograft survival. J Clin Invest 99:396-402.

Sugimoto K, Shiraki K, Ito T, Fujikawa K, Takase K, Tameda Y, Moriyama M, and Nakano T (1999). Expression of functional CD40 in human hepatocellular carcinoma. Hepatology 30:920-926.

Walczak H, Miller RE, Ariail K, Gliniak B, Griffith TS, Kubin M, Chin W, Jones J, Woodward A, Le T, Smith C, Schuh JCL, and Lynch DH (1999). Tumoricidal activity of tumor necrosis factor-related apoptosis-inducing ligand in vivo. Nat Med 5:157-163.
Wang CY, Mayo MW, Korneluk RG, Goeddel DV, and Baldwin AS Jr (1998). NF- $\kappa$ B antiapoptosis: Induction of TRAF1 and TRAF2 and C-IAP1 and C-IAP2 to suppress caspase-8 activation. Science 281:1680-1683.

Wiley SR, Schooley K, Smolak PJ, Din WS, Huang CP, Nicholl JK, Sutherland GR, Smith TD, Rauch C, Smith CA, and Goodwin RG (1995). Identification and characterization of a new member of the TNF family that induces apoptosis. Immunity 3:673-682.

Yamanaka T, Shiraki K, Sugimoto K, Ito T, Fujikawa K, Ito M, Takase K, Moriyama M, Nakano T, and Suzuki A (2000). Chemotherapeutic agents augment TRAIL-induced apoptosis in human hepatocellular carcinoma cell lines. Hepatology 32:482-490.

Yoong KF, Afford SC, Randhawa S, Hubscher SG, and Adams DH (1999). Fas/Fas ligand interaction in human colorectal hepatic metastases: A mechanism of hepatocyte destruction to facilitate local tumor invasion. Am J Pathol 154:693-703.
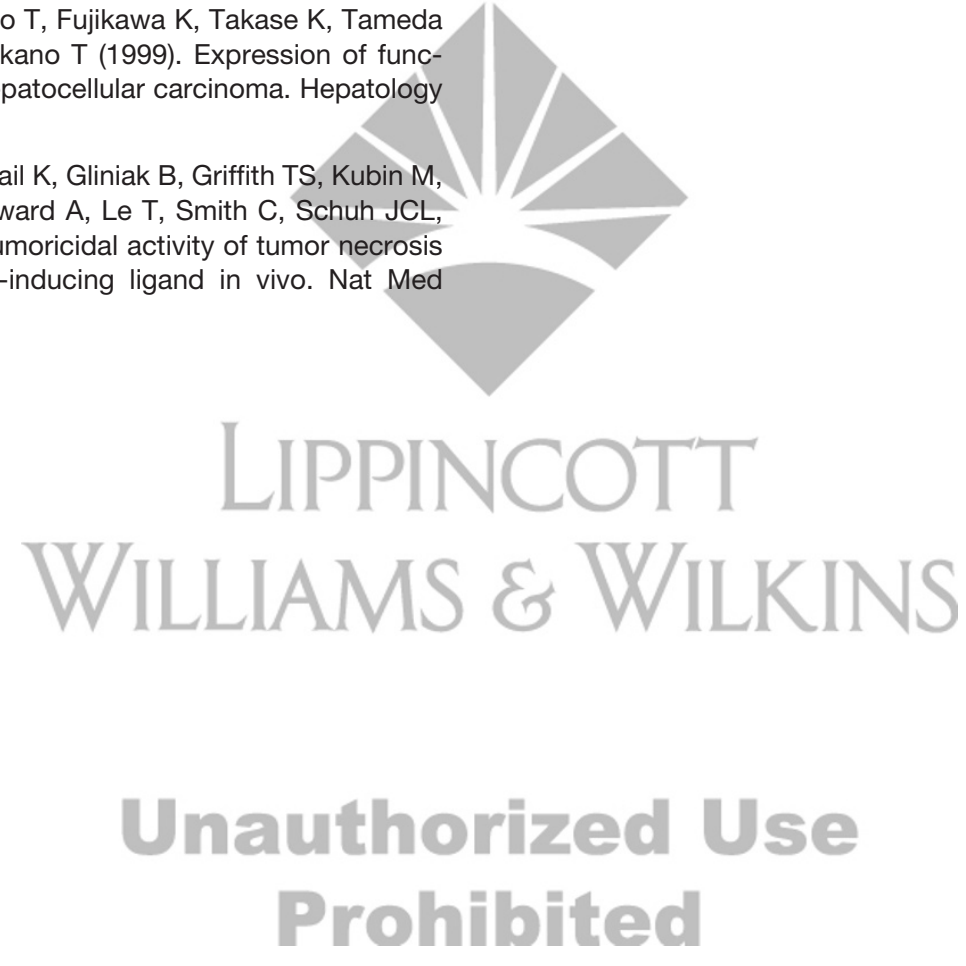